\title{
Analytical model of innovation ecosystem development
}

\author{
Evgeny Popov ${ }^{1}$, Ruslan Dolghenko ${ }^{1}$, Victoria Simonova ${ }^{1}$, and Igor Chelak ${ }^{1 *}$ \\ ${ }^{1}$ Ural Institute of Management, Branch of the RANEPA, 8 Marta str. 66, 620144 Yekaterinburg, \\ Russian Federation
}

\begin{abstract}
The fundamental challenges faced by the global economy with the advent of the COVID-19 pandemic and the prospects for re-globalization provide opportunities for the intensification of the development of new forms of coordination of economic relations - innovative ecosystems (regional, industrial, entrepreneurial). It seems that economic relations are built within the framework of a particular ecosystem, and the scientific descriptive and predictive analytics are not sufficiently able to describe their nature and the main patterns of growth. In order to provide a theoretical and practical contribution to the developing ecosystem approach, the article presents an analytical model of the innovation ecosystem of a high-tech company, proposed for evaluating and comparing its level of development. Research methods include content analysis of scientific literature devoted to the study of innovative ecosystems and approaches to their assessment, system analysis and factor modeling. The research fundament is based on the dynamics of indicators of innovative development of the ecosystem of a large production company in the Sverdlovsk region for 2013-2019. The model was tested according to the indicators of 2018. Further directions of the research in the practical aspect will consist in a comparative analysis of other periods of the company's activity, as well as in the application and verification of the model on the indicators of other organizations. Justification of the possibilities of creating technologies for managing the innovation ecosystem is seen as a theoretical component of future research.
\end{abstract}

\section{Introduction}

The exponential growth of the possibilities of information and communication technologies [1] in recent years determines a particularly attentive attitude to the application of the achievements of scientific and technological progress. The $21^{\text {st }}$ century will be a test for humanity. The increasingly complex social, political, economic, climate, resource, and energy contradictions should direct the efforts of States, companies, and civil society to overcome the pitfalls and gaps in development. Joint effective actions of economic and political stakeholders should ensure a steady forward movement towards a harmonious society and well-being for all. The implementation of such a paradigm does not look like a

\footnotetext{
*Corresponding author: chelak@mail.ru
} 
utopian project. This thesis proves re-globalization (regionalization) [2], the formation of new types of relations of companies within a certain territory [3], the deployment of local innovation ecosystems. These processes are of growing interest to the scientific community and government officials [4-6].

The Ecosystem dynamics allows for product customization [7], technological improvement, increasing the level of trust of economic entities [8] and, as a result, reducing the share of transaction costs $[9,10]$. The innovative orientation of entrepreneurs is more important today than ever. We support the thesis that the reengineering of business models should be focused on strengthening ecosystem relations with all stakeholders of the company $[11,12]$. The development of the ecosystem approach to the study of economic relations requires a transition from the theoretical and methodological discussion of the concept of ecosystems, their typology and scientific perspectives of the ecosystem paradigm to the development of practical tools for analyzing this form of coordination of economic activity, in particular, in the real sector of the economy. The methods of analyzing the ecosystem of innovative companies are not sufficiently presented in the scientific literature. This study publishes the results of the development of an analytical model for evaluating the ecosystem of an innovative company based on the identification of its key stakeholders and the factors associated with them that affect the output of innovative products.

The main research hypothesis is to identify five groups of stakeholders in the innovation ecosystem and twelve factors whose changes significantly affect the company's production of the latest products and services.

\section{Materials and methods}

The purpose of the study is to develop a model for evaluating the ecosystem of an innovative company. The methods for solving this problem include the analysis of current scientific research, systematization and factor modeling, and are based on the use of the author's scheme of the stakeholder innovation ecosystem [13], practical experience, and the study of the impact of economic, social, cultural, institutional and other factors on the dynamics of the production activity of a large high-tech Russian company that produces civil and defense products for the period 2013-2019.

Table 1. An array of initial indicators of the innovative company's activity for 2013-2019*

\begin{tabular}{|c|l|l|}
\hline No. & \multicolumn{1}{|c|}{ Indicator } & \multicolumn{1}{c|}{ Source of information } \\
\hline $\mathbf{1}$ & \multicolumn{1}{|c|}{$\mathbf{c}$} \\
\hline 1 & Total revenue & Statement of financial results \\
\hline 2 & Revenue from sales of innovative products & Management accounting \\
\hline 3 & Revenue from sales of civilian products & Management accounting \\
\hline 4 & Revenue from sales of special products & Management accounting \\
\hline 5 & Revenue from sales in the domestic market & Management accounting \\
\hline 6 & Revenue from sales in the foreign market & Management accounting \\
\hline 7 & Number of employees & Management accounting \\
\hline 8 & Asset value & Balance sheet \\
\hline 9 & Number of competitors & $\begin{array}{l}\text { Aggregator of statistical information on } \\
\text { economic entities (https://www.spark- } \\
\text { interfax.ru/) }\end{array}$ \\
\hline 10 & Amount of taxes & Management accounting \\
\hline 11 & Average salary & Management accounting \\
\hline
\end{tabular}




\begin{tabular}{|c|c|c|}
\hline 12 & $\begin{array}{l}\text { Construction in progress and unfinished } \\
\text { operations for the acquisition, } \\
\text { modernization, etc. of fixed assets }\end{array}$ & Balance sheet \\
\hline 13 & Revenue from sale/lease of idle assets & Management accounting \\
\hline 14 & $\begin{array}{l}\text { Proceeds from the sale of non-current } \\
\text { assets }\end{array}$ & Balance sheet \\
\hline 15 & Cost of material costs & Balance sheet \\
\hline 16 & $\begin{array}{l}\text { Costs associated with losses (shortfall, } \\
\text { damage, overproduction, formation of } \\
\text { unused further waste, etc.) }\end{array}$ & Management accounting \\
\hline 17 & Revenue from service & Management accounting \\
\hline 18 & Number of consumers of products & Management accounting \\
\hline 19 & Number of suppliers & Management accounting \\
\hline 20 & $\begin{array}{l}\text { Number of scientific and educational } \\
\text { partners }\end{array}$ & Management accounting \\
\hline 21 & $\begin{array}{l}\text { Number of government and local } \\
\text { government partners }\end{array}$ & Management accounting \\
\hline 22 & $\begin{array}{l}\text { Number of partners from public } \\
\text { organizations }\end{array}$ & Management accounting \\
\hline 23 & $\begin{array}{l}\text { Indicators of educational programs } \\
\text { on innovation and management topics }\end{array}$ & Management accounting \\
\hline 24 & R \& D expenses & Balance sheet \\
\hline 25 & Social project costs & Management accounting \\
\hline 26 & $\begin{array}{l}\text { The number of positive ratings of the } \\
\text { company in the media and social networks }\end{array}$ & Management accounting \\
\hline 27 & $\begin{array}{l}\text { The number of negative ratings of the } \\
\text { company in the media and social networks }\end{array}$ & Management accounting \\
\hline
\end{tabular}

* numerical data is not provided due to restricted access mode

The subject of the study is the economic relations between the stakeholders of the company's innovation ecosystem, which determines the need to include the identification and systematization of groups of stakeholders with similar institutional foundations among the research methods.

\section{Empirical model}

The extraction of the role value of conditionally internal and external actors allowed us to identify five groups of stakeholders in the ecosystem of an innovative company, indicated in Table 2. Out of several dozens of eco-factors (the term is borrowed from Kansheba [14]), the expert method revealed the indicators on which the share of sales of innovative products of the company should most depend.

It can be argued that it is inappropriate to refer staff and society to related stakeholders and include them in a single group. However, this inversion is precisely the expression of the general environmental feature of the ecosystem approach. The latter seeks to remove the limitations of strategic management and its key paradigm of dividing the environment into external and internal. Personnel, mainly as a social phenomenon, is difficult to unambiguously attribute to one of these environmental components. 
Table 2. Grouping of the main stakeholders of an innovative company

\begin{tabular}{|c|c|c|c|c|}
\hline "Consumers" & $\begin{array}{c}\text { "Competitors } \\
\text { and } \\
\text { suppliers» }\end{array}$ & "Power" & "Society" & $\begin{array}{c}\text { "Science and } \\
\text { Education" }\end{array}$ \\
\hline $\begin{array}{c}\text { Customers in the } \\
\text { foreign market }\end{array}$ & Competitors & $\begin{array}{c}\text { Federal } \\
\text { Government }\end{array}$ & Civil society & $\begin{array}{c}\text { Scientific } \\
\text { institutions }\end{array}$ \\
\hline $\begin{array}{c}\text { Customers in the } \\
\text { domestic market }\end{array}$ & Suppliers & Regulators & MASS MEDIA & $\begin{array}{c}\text { Scientific } \\
\text { workers of the } \\
\text { organization }\end{array}$ \\
\hline $\begin{array}{c}\text { Customers of civil } \\
\text { products }\end{array}$ & $\begin{array}{c}\text { Shareholders/ } \\
\text { Investors }\end{array}$ & $\begin{array}{c}\text { Regional } \\
\text { authorities }\end{array}$ & Social Media & $\begin{array}{c}\text { Educational } \\
\text { institutions }\end{array}$ \\
\hline $\begin{array}{c}\text { Customers of special } \\
\text { products }\end{array}$ & $\begin{array}{c}\text { Management } \\
\text { governments }\end{array}$ & $\begin{array}{c}\text { Personnel as a } \\
\text { social group }\end{array}$ & $\begin{array}{c}\text { Corporate } \\
\text { Universities }\end{array}$ \\
\hline & $\begin{array}{c}\text { Banks and } \\
\text { development } \\
\text { institutions }\end{array}$ & & $\begin{array}{c}\text { Individual } \\
\text { communities }\end{array}$ & \\
\hline
\end{tabular}

The systematization of stakeholders and the relevant experience of evaluation [15] allowed us to form a hypothesis about the model for evaluating the ecosystem of an innovative company, described by the following equation, where the desired indicator $(\mathbf{y})$ is the share of innovative products.

$$
y=k_{1} \cdot i_{\frac{c}{100}}+k_{2} \cdot i_{\frac{b}{100}}+k_{3} \cdot i_{\frac{\rho}{100}}+k_{4} \cdot i_{\frac{s}{100}}+k_{5} \cdot i_{\frac{e s}{100}}
$$

\section{Results and discussions}

Speaking about the ecosystem of a commercial enterprise, the main characteristic that indicates its innovative orientation will be the volume of innovative goods and services sold in total sales. In the Russian Federation, the importance of this indicator is emphasized at the state level, it is included in the mandatory statistical reporting of enterprises [16]. This indicator comprehensively reflects the innovative focus of the organization, the potential for participation in regional and national scientific and technological development. This indicator allows us to formulate judgments about the quality characteristics of consumers of the company's products, their interest in the latest, high-tech products. According to the company, the share of sales of innovative products in 2018 was 9 percent.

We will reveal the values of the variables of the analytical model:

1. $i_{c}$ (customers): consumers of products and services

$$
\left.i_{c}=0,4 * \text { (share of special purpose products }\right)+0,6^{*} \text { (share of exports) }
$$

The weight coefficients in each sub-formula hereafter are assigned by the expert method.

1.1. The share of sales of special-purpose products (as opposed to civilian products) shows, firstly, the high technological level of the company, and secondly, the degree of competitiveness of the manufacturer. Contracts for the supply of such goods are mainly concluded by Russian and foreign customers in conditions of critical attitude to the quality of products. The 2018 index according to the company's data was 83 percent, which indicates 
a significant level of the company's efforts aimed at achieving high indicators of consumer properties of its products.

1.2. Export operations demonstrate the superiority or identity of the quality and price characteristics of the company's products on the foreign market. Despite the difficult sanctions and image conditions that have developed since 2014 for Russian organizations in foreign markets, the share of exports according to the company's data in the analyzed period was a significant share -39 percent.

2. $i_{b}$ (business): competitors and suppliers

$$
i_{b}=0,4 * H H I \text { (competitors) }+0,6 * H H I \text { (suppliers) }
$$

2.1. The choice of the Hirfendahl-Hirschmann Index (HHI) is determined by the hypothesis of the complexity of ecosystems in nature [17]. Using an interdisciplinary approach, we believe that "biodiversity", a complexity characterized by a large number and species diversity of business units, is important and productive in the economic ecosystem as well as in the ecological environment. Conclusions from the theory of competition also defend our judgment [18]. The Hirfendahl-Hirschman index shows the level of concentration of the relevant markets and indirectly indicates the tendencies towards monopolization of the market. All other things being equal, the pronounced monopolistic factors reflect the lack of efficiency of the existing market structure [19], therefore, simplifying, the more competitors and suppliers a company has, the higher the potential for ecosystem development: the greater the opportunities for one-time or permanent collaboration, joint projects, and the choice of market niches.

On the other hand, the approach of the considered indicator to the level of perfect competition weakens the company's ability to direct the necessary financial and other resources for the implementation of innovative developments. However, such a threat is unlikely for the market of technological products, which has high barriers to entry.

In relation to competitors, the Hirfendahl-Hirschman index is calculated for the industry "Production of industrial goods and services" [20], which the SPARK-Interfax system refers to the analyzed company. The calculated value shows the degree of monopolization of the industry (and with additional calculations, the company's share in the industry). The 2018 index was 686.68. Based on the standard index scale, the market is highly competitive. To normalize the indicator, we introduce an interpretation of the index as a percentage. Taking into account the boundaries of the corridor of index values (from 0 to 10000), the indicator for 2018 was $6.9 \%$.

2.2. Let us consider payments to suppliers as a quasi-industry for calculating the degree of monopolization-the company's dependence on certain counterparties. The 2018 Hirschmann-Herfindahl index is $1063.01(10.6 \%)$. The market is not fully competitive. Dependence on a number of suppliers is likely.

\section{3. $i_{\rho}$ (power)}

$$
i_{\rho}=0,6 * \text { tax burden }+0,3 * \text { compliance with the rules }+0,1 * \text { regulations acts }
$$

3.1. The tax burden is calculated according to the SPARK-Interfax system (tab "calculation of coefficients"), and in 2018 it was $11.8 \%$. For verification, the average tax burden for the industry was requested, which also amounted to $11.8 \%$ for the analyzed period [21].

3.2. The institutional component of the model includes two factors: the company's compliance with the mandatory rules and the regulatory legal acts (NPA) adopted in relation to the organization in question. Both indicators reflect the state's focus on the company's 
current activities and illustrate the color of interaction in the ecosystem. The first index is calculated as the ratio of the number of violations of mandatory requirements and standards detected by the supervisory authorities to the number of inspection units per year (according to the SPARK-Interfax system). The index was $=144 \%$ ( 8 checks at 18 addresses, 26 violations were detected).

3.3. The NPA index was calculated as the ratio of the number of regulatory and legal acts adopted at both the federal and regional levels in relation to the company for 2018 to the total number of acts (publicly available on official websites on the Internet) concerning the economic entity under study [22]. Calculations based on the results of 2018 give an indicator of $8.5 \%$.

4. $i_{s}$ (society)

\section{$i_{s}=0,6 * W+0,1 *$ share of spending on social projects + \\ $0,3 *$ reviews in the mass media and social media}

The group of stakeholders "Society" is proposed to include the sector of social actors in their isolation from the economic and government sectors [23], in alliance with the" fourth power" - the mass media and social media (social networks) [24]. The main calculated coefficients of ecosystem interactions in this cluster of the analytical model are the following eco-factors:

4.1. The ratio of the average salary for the enterprise to the average salary for the region (W) [25]. Calculations based on the results of 2018 give an indicator of $126 \%$, which with a high degree of probability indicates a fairly high level of professionalism of the company's employees;

4.2. Share of expenditures on social projects. In 2018, according to the company, the indicator was $2.1 \%$. In comparison with the volume of other expenses, the revealed indicator does not look significant. However, when calculating the average value - the amount of social expenses per employee of the company, the total coefficient indicates an increased level of social responsibility of the company's management.

4.3. The ratio of positive reviews in the media and social media to the total number of reviews. According to the data provided by the company, in 2018 the figure was $94 \%$.

The first and second terms of the formula also characterize the impact of the company on the quality of social capital in the external and internal circle of the ecosystem. The third term of the formula reflects the inclusion of the company's ecosystem in the positive federal and regional agenda.

5. $i_{e s}$ (education and science): the scientific and educational component of the ecosystem

$$
\begin{gathered}
i_{\text {es }}=0,2 * \text { share of } R \& D \text { expenditures }+0,5 * \text { share of researchers in the region }+ \\
\qquad 0,3 * \text { share of partners }
\end{gathered}
$$

5.1. The ratio of expenses for research and development (R\&D) to the total amount of expenses demonstrates the intensity of innovation activity in the company. The indicator in 2018 was $4.25 \%$;

5.2. The share of researchers in the region reflects the general "background" of the representation of science in the territory. For the Sverdlovsk region, this figure was $0.95 \%$ [26] of the total number of employees in 2018, which is significantly higher than in most other regions of Russia. This fact is explained primarily by the fact that the Ural Branch of the Russian Academy of Sciences is located in the Sverdlovsk region. 
5.3. The ratio of the number of partners of the company from the total number of scientific and educational organizations in the region of presence allows us to identify the degree of development of communication with the considered segment of the regional innovation meta-ecosystem. The company's data for 2018 was $5.8 \%$. Testing the model on the indicators of 2018 gives the following results:

$$
\begin{aligned}
& i_{c}=0,4 * 83+0,6 * 39=56,6 \\
& i_{b}=0,4 * 6,9+0,6 * 10,6=9,1 \\
& i_{\rho}=0,6 * 11,8+0,3 * 144+0,1 * 8,5=51,13 \\
& i_{s}=0,6 * 126+0,1 * 2,1+0,3 * 94=104 \\
& i_{e s}=0,2 * 4,25+0,5 * 0,95+0,3 * 5,8=3 \\
& y=k_{1} \cdot 56.6 / 100+k_{2} \cdot 9,1 / 100+k_{3} \cdot 51.13 / 100+k_{4} \cdot 104 / 100+k_{5} \cdot 3 / 100 \\
& \quad 9=k_{1} \cdot 0,56+k_{2} \cdot 0,09+k_{3} \cdot 0,51+k_{4} \cdot 10,4+k_{5} \cdot 0,03
\end{aligned}
$$

Key to the assessment of innovative ecosystems are stakeholder relationships, through which disparate organizations and other components of the socio-economic environment self-organize into ecosystems. At the same time, the energy that ensures the viability of the ecosystem is produced by the innovative orientation of the actors. Innovations are the essential basis of ecosystems in the social world, and if we are talking about a production, entrepreneurial ecosystem, a high - tech company-innovations here determine the survival, ensure the viability of the ecosystem, and competitiveness. By creating ecosystem effects, a permanent focus on the initiation, development, and dissemination of innovative ideas and products (R\&D, new products and services, advanced technologies, continuous improvements in production, management, sales, service, communications, etc.) keeps the company, its employees, and stakeholders in good shape. Hence, the main objects of attention for orchestration in the ecosystem of the degree of innovation are seen as:

- the number and quality of internal and external impacts on innovation in its broadest sense;

- $\quad$ corporate and regional culture of support for new developments;

- external factors that particularly affect the innovation dynamics.

Giving priority to the (conditional) external environment, having developed a grouping of stakeholders and singling out the eco-factors of this segment of the innovation ecosystem, we have obtained an analytical model for assessing the eco-system, which takes into account:

a) the focus of consumers on access to the latest products, business ties, monopolistic influence of suppliers, competitors;

b) the complex impact of state structures that set a high bar through the institutional environment, national priorities (projects on import substitution, labor productivity, export expansion, introduction of digital technologies);

c) environmental social impact on the ecosystem;

d) the role of the scientific and educational environment, professional communities, and development institutions that are ready to provide impulses, resources, and expertise for the development of highly competitive production activities, establishing new contacts, and intensifying them.

The innovation ecosystem, which represents the unity of the socio-economic, cultural, and institutional environment and its constituent elements, by analogy with natural 
ecosystems, needs development resources. If the main resources (energy) of natural ecosystems are obtained through direct and indirect solar activity, then the energy impact in socio-economic ecosystems, which leads to their innovative evolution and expansion, is carried out at the expense of the key economic factor in the present increasingly complex world - entrepreneurial ability, without which neither labor, nor land, nor capital, nor information can be converted into meaningful goods.

The biggest innovations in the economy of recent decades clearly demonstrate how closely you need to work with other companies, organizations, and communities to create something much more complex, unique, and breakthrough. A single company will not be able to independently produce an iPhone, build and maintain a Large Hadron Collider, send an expedition to Mars, or develop high-tech (medical, optical, computer) equipment.

\section{Conclusions}

This article provides an example of a stakeholder analytical model, which is used to evaluate the level indicators of the innovation ecosystem of a high-tech company. The groups of stakeholders surrounding the company and embedded in its ecosystem are identified. Expert methods have been used to find eco-factors of the following components of the eco-system environment: client, business, government, public, scientific and educational. An example of the calculation of the model according to the data of 2018 of one of the largest high-tech companies in the Sverdlovsk region is presented. The next stage of research will be testing the model for a significant period of time, as well as at other enterprises.

The growth of computer capacity and the development of modern software should lead to the possibility of mathematical modeling and evaluation of the entire range of factors that affect ecosystems, both "local" and global, covering most socio-economic processes, up to the world economy as a super-ecosystem.

If one contemplates upon a more approximate stage of the evolution of the ecosystem approach, further study of ecosystem interactions requires careful attention to prioritization, ranking the importance of individual stakeholders. It seems that the entrepreneurial component is the main, meta-element that connects environmental relations to the ecosystem. Hence the importance of a detailed analysis of the control effects on the relations in the environment, management systems and technologies in the innovation ecosystem.

\section{Acknowledgements}

The article was supported by the Russian Foundation for Basic Research grant No. 20-01000333.

\section{References}

1. L. Thomson, A. Kamalaldin, D. Sjödin, V. Parida, International Entrepreneurship and Management Journal, 1-28 (2021)

2. Z. Wang, Z. Sun, Journal of Chinese Political Science, 26(1), 69-87 (2020)

3. A.E. Plakhin, I.N. Tkachenko, M.V. Evseeva, Bulletin of the NGIEI, 8(111), 51-59 (2020)

4. L. A. Ramenskaya, The Manager, 4, 16-28 (2020)

5. Ya.Yu. Radyukova, Yu.K. Arkhipova, V.Yu. Sutyagin, E.A. Kolesnichenko, Izvestiya Yugo-Zapadnogo gosudarstvennogo universiteta. Series: Economics. Sociology. Management, 9 (6), 29-38 (2019)

6. Government of the Russian Federation, http://www.garant.ru (2020) 
7. B. Hilton, B. Hajihashemi, C.M. Henderson, R.W. Palmatier, Industrial Marketing Management, 90, 360-369 (2020)

8. A. Giovanini, P.F. Bittencourt, M. Uriona Maldonado, Revista Brasileira de Inovação, Campinas (SP), 19, e020005-e020005 (2019)

9. J.H. Dyer, Strategic Management Journal, 18 (7), 535-556 (1997)

10. B.N. Panshin, Nauka i innovatsii, 3 (157), 17-20 (2016)

11. M. Talmar, B. Walrave, K.S.Podoynitsyna, J. Holmströmc, A.G.L. Rommea, Long Range Planning, 53 (4), 101850 (2020)

12. M.O. Soldak, Econ. promisl, 4 (88), 38-66 (2019)

13. E.V. Popov, V.L. Simonova, I.P. Chelak, Innovation, 6 (260), 46-53 (2020)

14. J.M.P. Kansheba, Small Enterprise Research, 27 (2), 110-124 (2020)

15. D. Nepelski, V. Van Roy, The Journal of Technology Transfer, 1-36 (2020)

16. Konsultant.ru, http://www.consultant.ru/document/cons_doc_LAW_343020 (2021)

17. T.O. Kvålseth, Heliyon, 4 (10), e00846 (2018)

18. M. Porter, Competition (2000)

19. E. Carayannis, D. Campbell, International Journal of Social Ecology and Sustainable Development, 1(1), 41-69 (2012)

20. Spark, https://www.spark-interfax.ru (2021)

21. Nalog.ru, https://www.nalog.ru/rn77/taxation/reference_work/conception_vnp (2021)

22. Pravo, http://pravo.gov.ru (2021)

23. P. Oeij, S. Dhondt, S. Solley, A. Hill-Dixon, Atlas of Social Innovation Future (2018)

24. E.V. Popov, V.L. Simonova, O.V. Komarova, Bulletin of the UrFU, Series: Economics and Management, 18(2), 168-185 (2019)

25. Rosstat, https://rosstat.gov.ru/labor_market_employment_salaries (2021)

26. Rosstat, https://rosstat.gov.ru/folder/14477 (2021) 